\title{
Research and Exploration of the Excellent Course Construction of An Introduction to Automobile Service Engineering
}

\author{
Peijiang Chen \\ School of Mechanical and Vehicle Engineering \\ Linyi University \\ Linyi, China \\ chenpeijiang@163.com
}

\begin{abstract}
The construction of excellent courses is an important method to improve talent training in colleges and universities, and can effectively improve the teaching quality. An Introduction to Automotive Service Engineering is a key professional core course for the major of automotive service engineering, and it is a university-level excellent course for Linyi University. The teaching objectives of this course in terms of knowledge, ability and quality are introduced. Based on the industry needs of professionals, the course teaching content is reset. The curriculum system is rebuilt with the cultivation of innovation and entrepreneurship ability as the main line. A more detailed analysis of theoretical and practical teaching content of this course is given, and the basic ideas of online course resource construction are analyzed. The teaching practice proves that the construction of excellent courses can enrich teaching resources and reform teaching methods, thereby effectively improving teaching effectiveness and quality of personnel training.
\end{abstract}

Keywords-An Introduction to Automotive Service Engineering; Excellent courses; Curriculum system; Online courses

\section{INTRODUCTION}

The excellent course is a demonstration course with outstanding teachers, advanced teaching content, valid teaching methods, good teaching materials, and efficient teaching management. Since the beginning of the National Excellent Course Construction Project in April 2003 by the High Education Department of the Ministry of Education, the excellent course construction has received unprecedented attention in Chinese universities and has been taken as an important means for the quality of personnel training in colleges and universities [1]. At present, the excellent curriculum construction in China has formed a three-level system with national, provincial, and school levels. With the in-depth development of excellent courses construction in colleges and universities, the research of excellent courses has become the focus of attention [2].

Since entering 21 st century, with the rapid development of the automobile industry in China, it has become a pillar industry of the national economy. As a result, automobile

This study was supported by the Teaching Quality Engineering Projects of Linyi University in 2014, 2016 and 2017. services have also developed into a market with huge potential The automobile service industry is becoming more and more important. It has extensive and broad content, including technical services and non-technical services in the entire process from the time the offline to recycling and scrapping. The demand for high-quality talent in the automobile service industry from automakers and automobile service providers has received unprecedented attention [3].

In order to meet the needs of education towards world, future and modernization, the content of course education is continuously updated, and new automobile service projects and content are continuously added to the course content. At the same time, it emphasizes the practicality of course content. The professional knowledge students have learned should closely combined with the production practices and scientific and technological development. It can strengthen the students' abilities to use comprehensive knowledge to analyze and solve problems. It can lay solid foundation of the talents training for the development of the automobile industry, especially the automobile service industry.

“Introduction to Automobile Service Engineering" is a professional core course for the major of automobile service engineering in Linyi University, and it is also an important elective course for the majors of vehicle engineering and automobile application and maintenance technology. The course is an important construction achievement of the automobile service engineering particular specialty and automobile detection and maintenance teaching team. As an important job content of automobile industry, automobile service is an important teaching content in the professional course system since setting up of automobile service engineering.

With the construction of several years, the course teaching team has accumulated relatively rich teaching resources and has reformed teaching methods and student learning evaluation methods, achieving certain results. The course of Introduction to Automobile Service Engineering was rated as excellent course in Linyi University. 


\section{COURSE TEACHING OBJECTIVE}

The course of Introduction to Automobile Service Engineering mainly introduces the areas covered by modern automobile services, the methods, industry specifications and market operating models of automotive services. It can enable students to master the methods, rules, and industry requirements of the automobile service industry, and further improve the students' professional capabilities, so that they can adapt to the job requirements of the automobile technology service industry as soon as possible. At the same time, it can make students to master the process of automobile related comprehensive service knowledge and standards, and lay the foundation for future student employment. The course is the basis for follow-up courses such as Automobile Insurance and Claims, Automobile Marketing, Second Hand Vehicle Identification and Evaluation.

\section{A. Knowledge objective}

Through the teaching of this course, students should recognize:

(1) Automobile service strategies, automobile technology service management policies and regulations, and automobile industry development policies;

(2) Automobile comprehensive service management policies and regulations;

(3) Knowledge of automobile legal services and development knowledge of the automobile integrated service market.

Through the teaching of this course, students should master:

(1) Operation methods and modes of automobile service fields such as automobile sales service, after-sales service, automobile beauty, automobile parts business, second hand vehicle trading, automobile service market development, automobile insurance, etc.;

(2) Automobile service models and concepts of different automobile companies;

(3) Standard processes of various automobile services.

\section{B. Capability objective}

Method capability objective:

(1) Cultivate students' abilities of being humble, studious, and knowledge transfer;

(2) Cultivate students' work styles of being diligent in thinking and working seriously.

Social capability objective:

(1) Cultivate students' abilities of strong verbal and written skills, good communication and coordination skills, and teamwork skills;

(2) Cultivate students' abilities of analyzing and solving problems;

(3) Cultivate students' abilities of information investigation, analysis and utilization;
(4) Cultivate students' abilities of awareness and safety awareness.

Professional capability objective:

(1) Be familiar with the areas covered by modern automobile services, the methods, industry specifications and market operating model of automobile services;

(2) Cultivate students to meet the needs of different customers, provide different service standards and requirements, and provide the satisfactory services for the automobile customers;

(3) Master the modern automobile service model and awareness, comprehensively grasp the methods, rules, and industry requirements of the automobile service industry, and improve the students' professional capabilities, and be able to adapt to job demands as soon as possible.

\section{Quality objective}

(1) Have strong oral and written communication skills and interpersonal communication skills;

(2) Have hardworking, meticulous and rigorous work style and quality of communicating with others;

(3) Have good psychological quality and ability to overcome difficulties;

(4) Can establish good and lasting relationship with customers;

(5) Have strong professionalism and high sense of responsibility;

(6) Have good professional ability and strong spirit of innovation;

(7) Can improve students' overall quality.

In order to realize the teaching objectives of the course, it is need to optimize the teaching content based on the needs of enterprise. In order to cultivate applied talents, it is necessary to establish curriculum system by making the ability as the core Emphasizing the cultivation of students' ability in innovation and entrepreneurship is conducive to the sustainable development of the students.

\section{COURSE SYSTEM}

\section{A. Set course teaching content based on the needs of industry talents}

With the development of modern automobile technology, the society urgently needs a large number of high-quality applied talents in the automobile service field. Therefore, in the course teaching knowledge system, it is need to reasonably arrange the teaching methods and means of modern automobile marketing services, automobile logistics services, automobile after-sales services, automobile maintenance services, automobile financial services, and accidental vehicle damage claims services. The course of Introduction to Automobile Service Engineering and other courses, including Automobile Structure, Automobile Principles, Automobile Electrical and 
Electronic Technology, Automobile Marketing, and Automobile Detection and Diagnostics Technologies, Secondhand Vehicle Appraise and Assessment" and Automobile Insurance and Claims, constitute a follow-up relationship, thus forming a complete professional system to better meet the requirements for talents of Automobile service industry and enterprises.

\section{B. Build course system by taking innovation and entrepreneurship training as the thread}

A teaching system that integrates "theory, practice, and practice training" is constructed to cultivate students' comprehensive application ability by making the basic theory as the basis, using practice as an auxiliary teaching method, and practical training as comprehensive training. In the course teaching, the comprehensive practice can cultivate students' innovative spirit, setting up the scene of automobile service can cultivate students' entrepreneurial ability and create highquality applied talents.

\section{Establish practical platform by Focusing on the training of professional skills}

Based on the practical training bases inside and outside the university, the part of course teaching content is completed in automobile $4 \mathrm{~S}$ shops, repair shops, or testing stations. Through the cooperation of industry and education, the learning environment and work environment are combined to allow students to make contact real work process, which can not only improve the students' practical ability, but also help cultivate students' entrepreneurial ability.

\section{COURSE TEACHING CONTENT}

In order to adapt to the ever-changing social needs and personnel training needs, the teaching content of Introduction to Automobile Service Engineering is constantly updated.

\section{A. Theoretical teaching}

According to the curriculum syllabus, the theoretical teaching content is divided into 9 modules, and the content is arranged, as shown in Table 1.

TABLE I. THE THEORETICAL TEACHING CONTENT OF THE COURSE

\begin{tabular}{|c|c|c|c|}
\hline Content & Theory & Practice & Total \\
\hline Introduction of automobile service & 2 & & 2 \\
\hline Automobile marketing service & 10 & 2 & 12 \\
\hline Automobile logistics service & 4 & & 4 \\
\hline Automobile after-sales service & 6 & & 6 \\
\hline Automobile maintenance service & 4 & & 4 \\
\hline Automobile financial service & 4 & & 4 \\
\hline Automobile Insurance service & 4 & 2 & 6 \\
\hline Second-hand vehicle service & 4 & 2 & 6 \\
\hline Automobile recycling service & 4 & & 4 \\
\hline Total & 42 & 6 & 48 \\
\hline
\end{tabular}

\section{B. Practical teaching}

The practical part of this course is 6 lessons, and 3 comprehensive trainings can be arranged, as shown in Table 2.

TABLE II. THE PRACTICAL TEACHING CONTENT OF THE COURSE

\begin{tabular}{|c|c|c|}
\hline \multicolumn{1}{|c|}{ Practice item } & Practice type & Comprehensive \\
\hline Basic technical training of automobile marking & 2 \\
\hline Technology training of automobile insurance and claims & Comprehensive & Comprehensive \\
\hline Technology training of second hand vehicle identification and evaluation. & 2 & $\mathbf{6}$ \\
\hline Total & \\
\hline
\end{tabular}

\section{Innovation practice outside class}

In the course teaching process, it should cultivate entrepreneurial talents in the field of automobile services. The course content of Introduction to Automobile Service Engineering has strong practicality, and it includes the work content of the major automobile service industry. Under the premise of fully considering the needs of the industry talents, students are guided to conduct entrepreneurial practices and write business plans. Combining the implementation of the "Innovative experimental zone for entrepreneurial talents training model in the field of automobile services", the orientation of personnel training is updated and efforts are made to train talents in the automobile service industry with initial entrepreneurial abilities [4]. 


\section{ONLINE COURSE CONSTRUCTION}

The informatization of excellent course resources plays a very important role in achieving the sharing of teaching resources, improving the teaching quality and personnel training quality [5]. Online course construction is an important part of the excellent course construction. The implementation of online course construction and online teaching of Introduction to Automotive Services Engineering have a very stable and reliable network condition. Based on the online course center of Linyi University, it can make full use of all campus network interfaces of classrooms, laboratories, offices, and student dormitories throughout the school, which can conveniently meet and guarantee the implementation of the online teaching of the course.

In order to comprehensively improve the level of course construction, in the construction of excellent courses, it follows the principle of facilitating student use and the objective of improving the quality and effectiveness of course teaching to formulate scientific course construction plans, make full use of information technology, and absorb advanced online course construction concept, develop course content resources [6]. In the process of teaching, the reasonable course teaching design is adopted and scientific course evaluation methods are used [7].

The course website integrates the theoretical teaching and practical teaching resources of Introduction to Automobile Service Engineering. The teaching materials, such as teaching outlines, teaching plans, practical guidance, problem sets, test question banks, teaching videos, etc. have been online. The network course platform is interactive, and students can use online resources to learn and practice at any time.

In order to ensure the construction of high-quality course websites that meet the requirements, effective measures have been taken to ensure the normal operation, and the website can be maintained, upgraded, and updated frequently. It is easy for students to preview, review, and self-study. Through different network technologies, and the interaction between teachers and students have variety of forms, which can greatly facilitate students, stimulate students' enthusiasm for learning, and indeed play a role in improving teaching effectiveness. Then, the online course are welcomed by students.

\section{CONCLUSIONS}

Introduction to Automobile Service Engineering is an important course for automobile majors such as automobile service engineering. Through the joint efforts of the teaching team, the construction of Introduction to Automobile Service Engineering has achieved remarkable results. Efforts have been made in the construction of teaching staff, teaching content updating, and the construction of teaching resources. In the teaching process, teaching objectives are set with the industry needs, the teaching content is close to the market needs which are integrated into the classroom teaching, the course system is restructured, the teaching method reform is emphasized, the real automobile engineering project is integrated into the teaching, and case teaching method is used. These measures can fully arouse students' interest and enthusiasm, and cultivate students' professional qualities and innovation and entrepreneurship abilities.

In addition, due to the constraints of hardware and software, multimedia courseware, animation, and other teaching resources have yet to be further optimized and improved. The course group should further strengthen exchanges and cooperation with counterparts at home and abroad, absorb advanced experience, and output construction achievements, and further efforts should be made to improve the status and influence of the course.

\section{ACKNOWLEDGMENT}

This study was supported by the Teaching Quality Engineering Projects of Linyi University in 2014, 2016 and 2017.

\section{REFERENCES}

[1] F. Yang. Revelation of National Excellent Course Construction to Sharing Course of National Excellent Resource, Journal of Weinan Normal University, vol. 30, no. 20, pp. 45-51, 2015.

[2] J. Lei. The present Situation and Prospect of the Excellent Course Construction in Newly-built Colleges, Journal of Shenyang Normal University(Social Science Edition), vol. 38, no. 1, pp. 133-135, 2014.

[3] P. Chen. Reform and Construction of Curriculum System of Automobile Service Engineering Major, Advances in Social Science, Education and Humanities Research, vol. 157, pp. 346-349, 2017.

[4] P. Chen. Study and Practice of Entrepreneurial Talent Training Model in Automotive Service Field, Advances in Social Science, Education and Humanities Research, vol. 69, pp. 983-986, 2016.

[5] Z. He. The Study on the Digital Platform for Excellent Course Resources in Colleges and Universities, Journal of Jining Normal University, no. 3, pp. 37-40, 2017.

[6] B. Gu, and Y. Wu. The Exploration of Website Construction about College Excellent Course, Software Guide, vol. 13, pp. 2, pp. 175-177, 2014.

[7] G. Zhang, and F. Yang. Study on Construction Strategy of College Excellent Course Open Online Course, Journal of Weinan Normal University, vol. 31, no. 10, pp. 29-34, 2016. 